\title{
A Study on the Establishment of the Communist Party of Taiwan
}

\author{
Xiaoming Qiao \\ Journal Editorial Department, Yunnan Normal University, Kunming City, \\ Yunnan Province, 650092, China
}

\begin{abstract}
After the October Revolution in Russia, Lenin put forward the nation and colony theory from the strategic perspective of the world proletarian revolution. Under the guidance of the theory, the Communist International instructed the Communist Party of Japan to build the Communist Party of Taiwan. In November 1925, the Communist Party of China recommended Lin Mushun and Xie Xuehong to Moscow Oriental University of the Soviet Union to study, so as to prepare the establishment of the party. In October 1927, Xie Xuehong and Lin Mushun were summoned by the Communist International in Moscow. Pianshanqian conveyed the decision to build Communist Party of Taiwan to them on behalf of the Communist International. On April 15, 1928, under the guidance and with the help of the Communist Party of China, the Communist Party of Japan and the Communist International, Lin Mushun formally announced the establishment of the Communist Party of Taiwan.
\end{abstract}

Keywords: Communist Party of Taiwan; Communist International; Communist Party of China; Communist Party of Japan

\section{Introduction}

In the 1920s, the working class in Taiwan expanded steadily and the workers' and peasants' movement further developed, so that it desperately needed guidance of the advanced proletariat political parties and advanced theories. At the same time, with Japanese colonialists' repressive policies, as the leader of national movement in Taiwan, national bourgeoisie showed its weakness and compromise[1]. How to 
further the Taiwan national movement in the future became a grim subject faced by Taiwan proletariat. In this context, with the plan of the Communist International and Communist Party of Japan and under the direct leadership of the Communist Party of China, the Communist Party of Taiwan was built in Shanghai on April 15, 1928. Due to the limited materials and other reasons, there are few studies on the establishment of the Communist Party of Taiwan at present. Although some papers research it directly, there have not been any articles on this topic. In view of this, this paper intends to make a rough discussion on the establishment of the Communist Party of Taiwan.

\section{Communist International Guided and Prepared for the Establishment of the Communist Party of Taiwan}

In order to destroy the imperialist colonial system and form an international antiimperialist united front, Lenin put forward the nation and colony theory from the strategic perspective of the world proletarian revolution, which became the theoretical basis for the Communist International to guide the Eastern revolution. In order to break the encirclement of imperialism, to get rid of isolation in the world, and to consolidate the nascent Soviet regime, the Communist International and the Soviet Union urgently needed to establish friendly state relations and seek joint forces in the Eastern countries. Therefore, according to Lenin's nation and colony theory and the basic situation of the world, the Communist International decided to expand its scope of activities from the European countries to the Eastern colonial and semi-colonial countries. The Communist International used the above theory and strategic strategy to guide revolutionary movement in Taiwan[2].

In July 1920, at the second International Congress of the Communist International, the General Assembly adopted Lenin's Program on Nationalities and Colonies, which regarded the liberation movement of the oppressed nations and colonies as an important task of the Comintern. In January 1922, the East National Assembly emphasized the need to attach importance to the revolutionary movements of the oppressed peoples and colonies in Asia. In 1922 July, the inaugural meeting of Communist Party of Japan adopted the Draft Program of the Communist Party of Japan drafted by Bukharin, which expressly stipulated: "the Japanese army should retreat from Korea, China, Taiwan and Sakhalin." In November 1922, the General Assembly of the Fourth Congress of the Comintern adopted the Program of the Orient Problems. In December 1926, the Third Congress of the Communist Party of Japan adopted the Program of the Communist Party of Japan, which stipulated:" the Party's mission is to promote colonial independence under the rule of Japanese." Because the Communist International wanted to discuss the national and class problem, in July 1927, it adopted the Program on the Question of Japan drafted by Bukharin. This program defined that the Communist Party of Japan had the responsibility to guide the Korean movements and Communist Movements in Taiwan. In December in the 
same year, the Communist International instructed the Communist Party of Japan to organize Taiwan National Branch[3]. The Communist Party of Japan accepted this order and assumed the responsibility to support and guide the Taiwan Communist. As a result, the issue of the formation of the Communist Party of Taiwan emerged.

\section{The Preparatory Work for the Establishment of the Communist Party of Taiwan}

In 1925, the outbreak of the May 30th movement made Taiwan students in Shanghai directly experience this anti-imperialist and anti-feudal revolution. Around this time, a group of young Taiwanese students studied in Shanghai University, a red college co-founded by the Communist Party and the left wing of the Nationalist Party. Weng Zesheng entered sociology school in Shanghai University in July 1924 and he joined the Communist Part of China in the antiimperialist storm in 1925. In the same year, Xie Xuehong and Lin Mushun also came to the mainland and they joined into Shanghai Federation of Trade Unions and Red Relief. Therefore, in November 1925, Huang Zhongmei announced them the decision of the Central Committee of the Communist Party of China:" The Party ordered you to study at the Moscow Oriental University in the Soviet Union to cultivate cadres and build Communist Party of Taiwan in the future[4].

In November 1925, with the recommendation of the Communist Party of China, Lin Mushun and Xie Xuehong went to Moscow Oriental University of the Soviet Union to study in order to prepare for the establishment of the party in Taiwan. Basic members of the Communist Party may request the Communist Party of Japan and the CPC organizations to introduce the party's backbone members. After the establishment of the party, Xie Feiying and Lin Mushun went to Tokyo in Japan and conducted their work under the leadership of Central Committee of the Communist Party of Japan.

In order to complete this historical mission, in November 1927, Lin Mushun and Xie Xuehong returned to Shanghai and began to contact comrades (including some members of the Communist Party of China and the Communist Party of Japan)in the mainland, Taiwan and Japan. Then, they set up a Preparatory Committee of the Communist Party of Taiwan. In order to fulfill this important task of the Communist International, the Communist Party of China instructed the Taiwanese Communist Party member Weng Zesheng in Shanghai to help Lin Mushun and Xie Xuehong build the Communist Party of Taiwan. With the help of the Communist Party of China, they began to take action in two ways. Su Xin recommended Chen Laiwang who studied in Chengcheng College, Lin Tianjin studying at Nihon University and He Huoyan who studied in Waseda University. The five people established Taiwan Marxist Group, which was led by Lin Mushun. At the end of January 1928, Chen Laiwang returned to Shanghai along with Lin Mushun and Xie Xuehong. 
The Central Committee of the Communist Party of Japan attached great importance to the establishment of the Communist Party of Taiwan and they sent specially-assigned personnel to instruct the establishment of the General Assembly of the Communist Party of Taiwan. "We returned to Shanghai on the third day of our trip with Nabaiyama Sadaqika," he said, "he comes here to lead the establishment of the Communist Party of Taiwan on behalf of the Central Committee of the Communist Party of Japan." However, at this time, the Communist Party of Japan was preparing the general election and Guoshan returned to Japan. Therefore, the establishment of Communist Party of Taiwan was entrusted to the CPC[5].

On April 13, 1928, with the proposal of the representative Peng Rong of the Communist Party of China, the Taiwan Communist Activists Conference was held as a preparatory meeting for the establishment of the Communist Party of China. 11 people attended this meeting, including Lin Mushun, Xie Xuehong, Weng Zesheng, Xie Yuye, Chen Laiwang, Lin Higao, Pan Qinxin, Zhang Maoliang, Liu Shouhong, and Yang Jinquan who were Shanghai reading club activists. The meeting decided to hold the Party Congress on April 15, and examined, revised and adopted the Political Outline and Organization Outline (it was Translated into Chinese by Wengzesheng) drawn up by the Japanese Communist Party cadres, Watanabe Shiatsu and Sano, which was brought back from Tokyo. The meeting also revised and adopted plans and guidelines on issues such as labor movement, peasant movement, youth movement, women movement and red salvation association.

\section{The Specific Process of the Establishment of the Communist Party of Taiwan}

On April 15, 1928, according to the resolution in the Assembly of Activists, they held the General Assembly of the Founding of the Communist Party of Taiwan in the second floor of the King Father Photo Studio which was located at the intersection of Robbie Street and Xia Fei Road in Shanghai French Concession. Representatives included Pengrong of the Central Committee of the Communist Party of China and Lu Yunheng, Lin Mushun, Xie Xuehong, Weng Zesheng, Lin Rikao, Pan Qinxin, Chen Laiwang, Zhang Maoliang of the Communist Party of Korea.

The first agenda of the General Assembly was to declare the establishment of the Communist Party of Taiwan and the CPC Central Committee representative Peng Rong made a directing speech.

The meeting lasted a full day on the 15 th, the political program adopted on the day analyzed political and economic situation in Taiwan under the Japanese imperialist rule[6]. It pointed out that the nature of the current Taiwan people's revolution was a democratic revolution against imperialism and feudalism led by Taiwan proletariat. This revolution was a national revolution that overthrew the rule of the Japanese imperialists in Taiwan and a democratic revolution to carry 
out agrarian reform and eliminate the feudal exploitation system . The revolution was aimed at the Japanese imperialists and the feudal landlord class.

On April 20, the Central Committee of the Communist Party of Taiwan held another meeting to discuss the party-building declaration and draft a letter of thanks to the Communist Party of China for the assistance. The letter to the Communist Party of China expressed their gratitude to the people in Taiwan and thanks for the support and guidance of the CPC in Taiwan's party building and they hoped that such support would continue in the future"[7]. There are many members of the Communist Party of Taiwan who have joined the Communist Party of China who have been guided and trained by the Communist Party of China," the letter said, "Therefore, the establishment of the Communist Party of Taiwan had a close relationship with the Communist Party of China and the Taiwan revolution had much relevance with Chinese revolution. Therefore, we hope that the Communist Party of China can give guidance and support to the Communist Party of Taiwan, which was the warmest demand of all comrades of the General Assembly for the CPC." At this point, the inaugural meeting of the Communist Party of Taiwan was successfully concluded.

\section{Conclusion}

In summary, under the direct leadership of the Communist Party of China and with he help of the Communist International and the Communist Party of Japan, the Communist Party of Taiwan was established by Lin Mushun and Xie Xuehong. The establishment of the Communist Party of Taiwan was the objective need of the social progress and revolutionary development in Taiwan since modern times. Besides, it was an inevitable result of the interaction and development of various social, political and economic factors in Taiwan. It was also an inevitable result of the modern historical choice. The revolutionary program proposed by the Communist Party of Taiwan represented the direction of social development in Taiwan and represented the fundamental interests of the proletariat and the working masses. The establishment of the Communist Party of Taiwan not only brought the disaster-stricken people in Taiwan with trustworthy organizers and leaders, but also brought light and hope to Taiwan's national liberation movement. Since then, people' struggle in Taiwan against Japanese imperialism and feudalism entered a new stage and revolution in Taiwan took on a new look. The Communist Party of Taiwan had embarked on an indomitable and arduous struggle for the liberation of the people in Taiwan.

\section{References}

[1] Song Bangqiang. A Study on the Influence of the Communist Party of Taiwan om the Labor Movement during the Period of Japanese Occupation. Theory Monthly, (05), pp.93-98, 2016. 
[2] Song Bangqiang.A Study on the Relationship between the Communist Party of Japan and Communist Party of Taiwan during the Period of Japanese Occupation. Journal of the Party School of Tianjin University of the CPC, (06), pp.91-96, 2012.

[3] Yi Nan. Qu Qiubai Guided the Establishment of the Communist Party of Taiwan. Party Construction, (03), pp.63-64, 2010.

[4] Zhang Yuanxun. A Study on the Policy Evolution of the Peaceful Settlement of Taiwan Issue of the Communist Party of China. Journal of Tianzhong, (01), pp.5-9, 2010.

[5] Chen Zonghai. An Analysis of the Early Relationship between the Communist Party of China and the Taiwan Social Party Group. Journal of Adult Education College of Hubei University, (03), pp.11-13, 2003.

[6] Wang Jinyuan. A Research on the Process of the Establishment of the Communist Party of Taiwan. Sichuan Party History, (05), pp.61-62, 1994.

[7] Frank S. T. Shaw, Lawrence R. Sharivin and Tian Hua. A Study on the Political History of the Communist Party of Taiwan (1928-1931). Taiwan Research Quarterly, (02), pp.99- 105, 1986. 